\title{
ISOTOPES, INC. RADIOCARBON MEASUREMENTS IV
}

\section{MILTON A. TRAUTMAN}

Isotopes, Incorporated, Westwood, New Jersey

\section{INTRODUCTION}

The following list presents dates obtained on a fraction of the total number of measurements made during the years 1962 and 1963 and measurements made previously for which sample data has been recently received. The results which do not appear are withheld pending additional information, or at the request of clients.

Procedures employed in sample pretreatment, preparation of $\mathrm{CO}_{2}$ and method of counting and age calculation remain unchanged. Except for minor alterations, all information and comments are those of the persons submitting samples.

\section{ACKNOWLEDGMENTS}

It is recognized that data obtained at Isotopes, Inc. remain the sole property of our clients. Nevertheless we encourage our clients to submit these descriptions for publication and we wish to acknowledge the cooperation of all personnel mentioned in this list. In addition, we are indebted to Jerry M. Bonicos of Isotopes, Inc. for technical assistance in the laboratory.

\section{GEOLOGIC SAMPLES}

\section{A. Canada}

\section{Baffin Island series, Canada}

Marine mollusk shells from Baffin Island, North West Territories, Canada. Coll. and subm. 1961 and 1963 by V. M. Sim and J. D. Ives, Dept. Mines and Tech. Surveys, Ottawa.

\section{I-405. Ikpik Bay, $241 \mathrm{ft}$}

$6060 \pm 250$

4110 B.C.

Shells from E shore of Ikpik Bay (69 $19^{\prime} \mathrm{N}$ Lat, $75^{\circ} 37^{\prime} \mathrm{W}$ Long), 15 mi $N$ of Baird Peninsula, Baffin Island. From sandy bank with vertical range of less than $10 \mathrm{ft}$ at alt $241 \mathrm{ft}$. Alt is ca. $90 \mathrm{ft}$ below that of local postglacial marine limit.

\section{I-406. Ikpik Bay, $291 \mathrm{ft}$}

$6725 \pm 250$ 4775 в.c.

Shells from E shore of Ikpik Bay ( $69^{\circ} 10^{\prime} \mathrm{N}$ Lat, $76^{\circ} 28^{\prime} \mathrm{W}$ Long), $8 \mathrm{mi}$ $\mathrm{NE}$ of Baird Peninsula. From silt at alt $291 \mathrm{ft}$. Alt is ca. $40 \mathrm{ft}$ below that of local postglacial marine limit.

\section{I-485. Steensby Inlet, $28 \mathrm{ft}$}

$4000 \pm 180$

Shells from E coast of Steensby Inlet $\left(70^{\circ} 9^{\prime} \mathrm{N}\right.$ Lat, $71^{\circ} 35^{\prime} \mathrm{W}$ Long), $8 \mathrm{mi} \mathrm{S}$ of Rowley River estuary, Baffin Island. From center of mud circle $28 \mathrm{ft}$ above high tide. 


\section{I-487. Steensby Inlet, $70 \mathrm{ft}$}

Shells from E coast of Steensby Inlet ( $70^{\circ} 9^{\prime} \mathrm{N}$ Lat, $71^{\circ} 35^{\prime} \mathrm{W}$ Long). from silty sand on marine terrace at alt $70 \mathrm{ft}$.

\section{I-486. Steensby Inlet, $180 \mathrm{ft}$}

Shells from E coast of Steensby Inlet $\left(70^{\circ} 9^{\prime} \mathrm{N}\right.$ Lat, $71^{\circ} 35^{\prime} \mathrm{W}$ Long $)$, from center of mud circle $180 \mathrm{ft}$ above high tide limit.

General Comment (J.D.I.) : I-405, I-406, and I-485 to I-487 (this list) are the first dates from late-glacial and postglacial marine beaches and associated features available for NE Foxe Basin. I-486 represents the highest occurrence of marine mollusks in this area where the marine limit is $315 \mathrm{ft}$ above present high tide. This series indicates the rate of uplift of NE Foxe Basin during the late-glacial and postglacial isostatic recovery. Outwash terraces, associated with end moraines in the hinterland, are graded to base levels below the marine limit, and precise levelling should permit correlation of late-glacial marine and land-ice phases (Ives and Andrews, 1963).

\section{I-842. Wakeham Point, Canada}

$625 \pm 100$ A.D. 1325

Partially buried drift wood from smooth beach of bay $\mathrm{N}$ of Wakeham Point ( $74^{\circ} 50^{\prime} \mathrm{N}$ Lat, $110^{\circ} 25^{\prime} \mathrm{W}$ Long), Melville Island, N.W.T. Canada. Beach well protected from ice and storm-wave action by two peninsulas on which emerged beaches are well-developed and in places disrupted by icepushed ridges. Coll. 1962 by W. E. S. Henoch; subm. 1963 by J. D. Ives. Comment (W.E.S.H.) : height of $1.6 \mathrm{~m}$ represents the maximum possible movement of the land relative to sealevel that could have occurred since deposition of the driftwood. Despite allowance for the actual time of drifting, age and position of the wood corroborate I-840 and I-148 from the Dorset Culture site in McCormick Inlet, indicating that positive movement of the land has been slight through the past 1000 yr or more (Henoch, 1964, in press).

\section{I-840. McCormick Inlet, Melville Island, Canada \\ $1740 \pm 190$}

Moss peat from S shore of McCormick Inlet, Melville Island N.W.T., Canada $\left(112^{\circ} 7^{\prime} \mathrm{W}\right.$ Lat, $75^{\circ} 49^{\prime} \mathrm{N}$ Long), $1.8 \mathrm{~m}$ above high tide, from under flagstones in center of a Dorset Culture dwelling. Coll. 1962 and subm. 1963 by W. E. S. Henoch, Geog. Branch, Dept. Mines and Tech. Surveys. Comment (W.E.S.H.) : as it is unlikely that a dwelling would be built much closer to high water than $1.8 \mathrm{~m}$, it is assumed that age of the moss affords a good estimate of the positive movement of the land relative to sealevel since moss was buried. Artifacts among the dwellings were ident. as Dorset by W. E. Taylor, Nat. Mus. of Canada. Burned moss, found in the fireplace, was dated I (GSC) 148 as $1150 \pm 150 \mathrm{yr}$ old. Sample date I-840, Geol. Survey date I(GSC) -148 and the archeological evidence are consistent and suggest that positive movement of the land, for the last $1 \frac{1}{2}$ millennia has been appreciably less than $1.8 \mathrm{~m}$ (Henoch, 1964, in press). 


\section{I-841. Ross Point, Melville Island, Canada}

$7565 \pm 235$

5615 в.с.

Marine shells coll. on surface of terrace covered with sandy silt, Melville Island, N.W.T., Canada ( $107^{\circ} 14^{\prime}$ W. Lat, $74^{\circ} 55^{\prime} \mathrm{N}$ Long), $22 \mathrm{~m}$ above high tide. Coll. 1962 and subm. 1963 by W. E. S. Henoch. Comments (W.E.S.H.) : shells may not have been in situ when coll.; thus they cannot be related to a specific sealevel. Age and position implies only that about $7600 \mathrm{yr}$ ago the sealevel stood more than $22 \mathrm{~m}$ higher than today (Henoch, 1964, in press).

\section{I-730. Tingmisut Lake, Melville Island, Canada \\ $9075 \pm 275$ \\ 7125 в.C.}

Marine shells, Hiatella Arctica Linné $71.5 \mathrm{~m}$ above high tide, Melville Island, N.W.T., Canada ( $107^{\circ} 42^{\prime} \mathrm{W}$ Lat, $75^{\circ} 55^{\prime} \mathrm{N}$ Long), from surface of a broad terrace. Coll. and subm. 1962 by W. E. S. Henoch. Comment (W.E.S.H.) : shells represent highest recorded evidence of marine submergence on Melville Island. Age of $9075 \pm 275 \mathrm{yr}$ is probably minimum. Date is later than that related to southerly withdrawal of northern margin of last inland ice sheet on Victoria Island and does not coincide with general pattern of deglaciation. $\mathrm{C}^{14}$ dates indicate that classical Wisconsin ice margin must have withdrawn from $S$ shore of Viscount Melville Sound prior to $12,400 \pm 320$. Providing that higher and older mollusks are not found, it can be assumed that island was at least partially submerged beneath an ice cap covering several Queen Elizabeth Islands for some $3000 \mathrm{yr}$ after opening of S shore of Viscount Melville Sound (Henoch, 1964, in press).

\section{B. Africa}

Wadi Halfa Area series, Sudan

Carbonate gastropod shells in Wadi Halfa Township, Sudan.

\section{I-534. Wadi Halfa I}

$9325 \pm 250$

7375 B.C.

Carbonate gastropod shell, Cleopatra bulimoides, at foot of Jebel Halfa ( $21^{\circ} 55^{\prime} 40^{\prime \prime} \mathrm{N}$ Lat, $30^{\circ} 20^{\prime} 25^{\prime \prime} \mathrm{E}$ Long), $100 \mathrm{~m} \mathrm{E}$ of Nile, 2 mi above "Nile oyster bed" (I-531) in surficial silty gravel; alt $134 \mathrm{~m}$ above mean sealevel, and $12 \mathrm{~m}$ above Nile high water level today. Comment (R.W.F.) : gastropods are small (10-15 mm long) and numerous. Prepared for dating by cutting off tips of spires for complete cleaning. As empty gastropod shells normally float and mark floods, they date the last big oscillation of Nile (to $12 \mathrm{~m}$ above present). Date and level correspond closely with dates measured on oysters M-795 (9450 \pm 400$)$ and M-794 (9175 \pm 400) from El Hani near Abka (Michigan V), $23 \mathrm{~km}$ S of Wadi Halfa; representing a "high Nile" about $11 \mathrm{~m}$ above present (Fairbridge, 1962).

\section{I-531. Wadi Halfa Area 2}

$11,200 \pm 285$ 9250 в.C.

Pelecypod shell, (Etheria elliptica $\left(21^{\circ} 55^{\prime} 50^{\prime \prime} \mathrm{N}\right.$ Lat, $31^{\circ} 20^{\prime} 30^{\prime \prime} \mathrm{E}$ Long), $1000 \mathrm{mi}$ SE of Nile, at foot of Jebel Halfa, found 9 to $10 \mathrm{~m}$ above Nile flood level and, thus, $132 \mathrm{~m}$ above mean sealevel, in a gray silty gravel, the 
shells in part adhering, in growth position, directly to the Nubian Sandstone. Coll. 1961 and subm. 1962 by R.W. Fairbridge. Comment (R.W.F.) : site represents bed of former Nile, where the Etheria (Nile oyster) was covered by water all year round. The silty gravels are younger than the Sebilian and occupy a secondary valley filling when Nile flood level must have been 15 to $18 \mathrm{~m}$ above its present level (Fairbridge, 1962).

\section{I-533. Wadi Halfa Area 3}

$14,950 \pm 300$ 13,000 в.C.

Pelecypod shell, Unio wilcocksi ( $22^{\circ} 03^{\prime} 40^{\prime \prime}$ N Lat, $31^{\circ} 23^{\prime} 07^{\prime \prime}$ E Long), $300 \mathrm{~m}$ E of village of Nag Ikhtiariya, in Dubeira E district ( $15 \mathrm{~km} \mathrm{~N}$ of Wadi Halfa ), $20 \mathrm{~m}$ above Nile flood level, and thus $141 \mathrm{~m}$ above msl, in Sebilian silt, Associated with Corbicula, Viviparus and artifacts and mammal bone fragments. Coll. 1961 and subm. 1962 by R. W. Fairbridge. Comment (R.W.F.) : site is about the middle of the older Sebilian silts (darker and more consolidated than younger parts). Associated cultural material is latest Paleolithic, confirmed by the $\mathrm{C}^{14}$ date. This strong siltation phase (of unweathered calcareous and feldspathic silts) indicates large-scale desiccation in the headwaters of the Nile at Late-Glacial stage of the Würm. Unio individuals are only about 5 to $8 \mathrm{~cm}$ long, less than half the size of their modern equivalents (Fairbridge, 1962).

\section{I-441. Omega Creek series, Alaska}

$11,750 \pm 250$ 9800 в.c.

Wood twigs from placer-mine excavation of Montana Mining Co. in Omega Creek, Eureka Mining District, Tanana A-1 Quadrangle $\left(65^{\circ} 10^{\prime} 7^{\prime \prime} \mathrm{N}\right.$ Lat, $150^{\circ} 20^{\prime} 3^{\prime \prime} \mathrm{W}$ Long), Alaska. Imbedded in weathered silty peat having lenses of fine gravel underlain by $3 \mathrm{ft}$ of weathered pebble gravel and overlain by peat, silt and gravel $20 \mathrm{ft}$ thick. Coll. 1956 and subm. 1961 by D. M. Hopkins. Comment (D.M.H.) : sample helps establish age and rate of sedimentation of late Pleistocene fill in Eureka mining district. W-896, 4100 \pm 200 was coll. $8 \mathrm{ft}$. higher in this sequence (USGS VI, 1961).

\section{Barrow Ridge series, Alaska}

Peat from ridge at alt $28 \mathrm{ft}$ between Voth Creek and Village Slough, Barrow ( $71^{\circ} 17^{\prime} 50^{\prime \prime} \mathrm{N}$ Lat, $156^{\circ} 42^{\prime} 25^{\prime \prime}$ W Long), Alaska. Coll. 1962 by J. Brown, Cold Regions Research and Engineering Lab., Hanover, New Hampshire, and J. B. O'Sullivan, Iowa State Univ., Ames, Iowa.

\section{I-699. Barrow Ridge, $2 \mathrm{ft}$ depth $\quad 1775 \pm 120$}

Frozen peat inclusion at depth $2 \mathrm{ft}$ in silty frozen mineral soil of meadow tundra soil profile. Lower boundary in contact with massive ice wedge.

I-700. Barrow Ridge, 5 ft depth

$9550 \pm 240$

7600 в.C.

Frozen peat inclusion at depth $5 \mathrm{ft}$ adjacent to thin ice wedge. Represents lower boundary of peat inclusions in auger hole.
I-701. Barrow Ridge, $10 \mathrm{ft}$ depth
$10,525 \pm 280$

Frozen peat inclusion at depth $10 \mathrm{ft}$ from auger hole $3 \mathrm{ft} N$ of I-700. 
General Comment (J.B.) : dates in series do not exceed $\mathrm{C}^{14}$ dates for similar buried peat within area and at similar elevations. Shallowest sample (I-699) is associated with relatively recent peat accumulations and ice-wedge growth. Oldest sample (I-701) may have been buried by sedimentation or emplacement by thawing of ice-wedge from surface downward to present level, during a period of thicker active layer (Coulter, Hussey and O'Sullivan, 1960; Douglass and Tedrow, 1960; Péwé and Church, 1962).

\section{Eastern United States}

\section{I-421. Hackensack River Valley, Rockland County, $4000 \pm 200$ N. Y. No. 2 \\ 2050 в.C.}

Peat $\left(41^{\circ} 05^{\prime} 20^{\prime \prime} \mathrm{N}\right.$ Lat, $73^{\circ} 57^{\prime} 08^{\prime \prime} \mathrm{W}$ Long), about $.04 \mathrm{mi}$ W of Rte 303 and $0.21 \mathrm{~m} \mathrm{~S}$ of Rte 59 in Hackensack River Valley, near W Nyack, Rockland County, N. Y. Core sample of peat layer 19 to $20 \mathrm{ft}$ below land surface, overlying lacustrine silt and clay. Coll. and subm. 1958 by N. M. Perlmutter, Ground Water Branch, U. S. Geol. Survey. Comment (N.M.P.) : peat overlies deposits of Glacial Lake Hackensack (Perlmutter, 1959).

\section{I-422. Hackensack River Valley, Rockland County, $\quad 5625 \pm 175$ N. Y. No. 1 \\ 3675 B.C.}

Peat $\left(41^{\circ} 05^{\prime} 20^{\prime \prime} \mathrm{N}\right.$ Lat, $73^{\circ} 57^{\prime} 08^{\prime \prime} \mathrm{W}$ Long) about $.05 \mathrm{~m} \mathrm{~W}$ of Rte 303 and $0.21 \mathrm{~m} \mathrm{~S}$ of Rte 59 in Hackensack River Valley, near W Nyack, Rockland Co., N. Y. Core sample of peat layer 24 to $25 \mathrm{ft}$ below surface, overlying lacustrine silt and clay. Coll. and subm. N. M. Perlmutter. Comment (N.M.P.) : peat lies on deposits of Glacial Lake Hackensack (Perlmutter, 1959).

\section{ARCHAEOLOGIC SAMPLES}

\section{A. Alaska}

\section{Naknek Drainage series, Alaska}

Except as indicated in individual sample notations, all samples were coll. by D. E. Dumond during excavation in 1960 and 1961 by the Univ. of Oregon on 11/2 mi long Brooks River in Katmai Nat. Monument, and on the adjacent Naknek River of SW Alaska. All samples were subm. by L. S. Cressman in 1961. All comments by D. E. Dumond.

Archaeologic materials recovered have been divided into eight sequential cultural phases on both typologic and geologic grounds (Dumond, 1962, 1963). At Brooks River, chronological control of excavated material was assisted by the presence of five recognized superimposed deposits of volcanic ash. Of these, the uppermost (Volcanic Ash 1) is of known date, proceeding from the eruption of Mt. Katmai in 1912. All samples dated were from strata covered by this volcanic ash deposit, the only one recognized on the Nakned River. The relationship of cultural phases and volcanic ash deposits is schematically illustrated below. Charred wood associated with all phases except that designated Pavik, which falls entirely within the period of Russian and American contact, was subm. for age determinations. 


$\begin{array}{ccc}\text { Brooks River Volcanic } & \text { Brooks River } & \text { Naknek River } \\ \text { Ash Deposits } & \text { Phases } & \text { Phases }\end{array}$

Bluffs

Pavik

Ash 1 (A.D.) 1921)

- - . - .

Camp

Ash 3 - - - . - . - . - Falls - - .

Smelt Creek

Weir

Ash 4. - . . . . - . . . . - . - .

Hilltop

Ash 5 - - - - - - - - - - Gravels - - - -

\section{Brooks River Bluffs Phase}

Sample materials were from two sites located approx. $400 \mathrm{~m}$ apart on $\mathrm{S}$ bank of Brooks River, Alaska ( $58^{\circ} 35^{\prime} \mathrm{N}$ Lat, $155^{\circ} 44^{\prime} \mathrm{W}$ Long), from strata below Volcanic Ash 1 and above Volcanic Ash 2. Associated with rubbed slate implements and gravel-tempered pottery generally similar to late prehistoric Eskimo remains from elsewhere in Alaska.

\section{I-209. Brooks River Bluffs Phase, BR3-1}

$$
\text { A.D. } 1720
$$

$\mathbf{2 3 0} \pm \mathbf{8 0}$

Charred wood from a hearth located stratigraphically ca. midway in Bluffs Phase deposits at Site BR3-1. Coll. 1960. Comment: stratigraphically above Y-932, with age of $450 \pm 60$ (Yale VII), directly overlying deposit of Volcanic Ash 2 at BR3-1.

\section{Brooks River Camp Phase}

Sample materials were from Site BR1-2, located on N bank of Brooks River, Alaska $\left(58^{\circ} 35^{\prime} \mathrm{N}\right.$ Lat, $155^{\circ} 44^{\prime} \mathrm{W}$ Long), from strata below Volcanic Ash 2 and above Volcanic Ash 3. Associated with an artifact asemblage including both chipped and ground stone implements, as well as thick, graveltempered pottery, some of which bears paddle-impressed decoration in concentric circles, similar in both paste and decoration to pottery of the Birnirk Phase and others of N Alaska, from as early as ca. A.D. 800 (Penn IV). The two samples should bracket the Camp phase material.

\section{I-524. Brooks River Camp Phase, BR1-2,}

$$
\text { Upper }
$$

A.D. 1650

$$
300 \pm 75
$$

Charred wood from campfire remnant at extreme top of Camp Phase deposits at Site BR1-2, directly beneath an unbroken deposit of Volcanic Ash 2. Coll. 1961. Comment: sample appears younger than expected, in view of Brooks River Bluffs Phase determinations obtained on material from above Volcanic Ash 2. 


\section{I-525. Brooks River Camp Phase, BR1-2,}

$680 \pm 90$

\section{Basal}

A.D. 1270

Charred wood from fireplace at base of Camp Phase deposits at Site BR1-2. Coll. 1961.

\section{Brooks River Falls Phase}

Sample materials are from three hearths in Falls Phase deposits at Site BR5-1, on S bank of Brooks River, Alaska ( $58^{\circ} 35^{\prime} \mathrm{N}$ Lat, $155^{\circ} 44^{\prime} \mathrm{W}$ Long). Associated with an artifact assemblage including thick, barrel-shaped pottery with hair and vegetal temper, some of which is impressed on the exterior with a large diamond pattern, and implements of rubbed slate and flaked chalcedony and igneous rock, including series of small projectile points, some of which display pronounced barbs. These implements were previously separated into two phases (Dumond, 1962), but recent field work indicates they should be combined into a single cultural phase.

\section{I-519. Brooks River Falls Phase, BR5-1,} Hearth C

$1200 \pm 170$

A.D. 750

Charred wood from hearth at base of Falls Phase deposits at Site BR5-1, and located between ash deposits 3 and 4. Coll. 1961.

I-520. Brooks River Falls Phase, BR5-1, Hearth A

$975 \pm 120$ A.D. 975

Charred wood from hearth stratigraphically above Hearths B and C at BR5-1, and located above Volcanic Ash 3 but below Volcanic Ash 2, Coll. 1961.

\section{I-522. Brooks River Falls Phase, BR5-1,}

\section{Hearth B}

$1175 \pm 125$

A.D. 775

Charred wood from hearth near base of Falls Phase deposits at Site BR5-1, and located between deposits of Volcanic Ash 3 and 4. Coll. 1961.

\section{Brooks River Weir Phase}

Sample materials were from campsites from which were recovered implements predominantly of flaked dense igneous rock (notably a distinctive series of side blades), together with pecked and ground stone vessels, and hairtempered pottery bearing external impressions both of twined basketry and of a diamond-shape, paddle-impressed pattern. Implements of this phase have been separated on typologic grounds from those of the succeeding Brooks River Falls Phase, although recent research has demonstrated that this phase is ancestral to the Falls Phase. In view of $\mathrm{C}^{11}$ ages applicable to the Falls Phase and to the preceding Smelt Creek Phase (see below), an age spread of 1650 to 1450 for this phase seems acceptable, and is permissible if ages are considered with two standard deviations. Samples were from between Ash Deposits 3 and 4.

\section{I-210. Brooks River Weir Phase, BR7-1}

Charred wood from fireplace in a single-occupation campsite, BR7-1, on $\mathrm{E}$ shore of Brooks Lake ca. $120 \mathrm{mi}$ from head of Brooks River, Alaska (58 $35^{\prime}$ N Lat, $155^{\circ} 44^{\prime}$ W Long). Coll. 1960. 


\section{I-526. Brooks River Weir Phase, BR8-2}

$$
1230 \pm 150
$$

Charred wood from fireplace remains at Site BR8-2 on $\mathrm{N}$ bank of Brooks River, Alaska (58 $35^{\prime} \mathrm{N}$ Lat, $155^{\circ} 44^{\prime} \mathrm{W}$ Long), approx. $1200 \mathrm{~m}$ from Site BR7-1. Coll. 1961.

\section{Smelt Creek Phase}

Archaeologic materials assigned to this phase include a large quantity of check-stamped pottery as well as predominantly flaked stone implements, all generally similar to materials of Norton Culture of Norton Bay, which has age of $2213 \pm 110$ (Penn IV). Site SCl is outside area of Brooks River volcanic ash deposits, so that the Brooks River geologic (i.e., volcanic ash) evidence does not pertain. The only characteristic Smelt Creek Phase ceramics at Brooks River are in Site BR9-1.

\section{I-507. Smelt Creek Phase, SC1, Upper}

$150 \pm 75$

Scattered, charred wood from top of Smelt Creek deposit at Site SCl, located at the confluence of Smelt Creek and Naknek River, Alaska $\left(58^{\circ} 42^{\prime} \mathrm{N}\right.$ Lat, $156^{\circ} 42^{\prime}$ W Long). Coll. 1961 by W. A. Davis. Comment: sample originally expected to provide a terminal date for Smelt Creek Phase, but was found to have overlain also some materials reminiscent of the Brooks River Camp and later phases, which were intrusive into the Smelt Creek deposit. Accordingly, its recent age is in complete accord with the archaeologic evidence.

\section{I-508. Smelt Creek Phase, SCl, Lower}

$1900 \pm 150$

\section{A.D. 50}

Charred wood from Hearth at top of lowest $1 / 3$ of Smelt Creek Phase deposit at Site SCl, located at the confluence of Smelt Creek and Naknek River, Alaska ( $58^{\circ} 42^{\prime} \mathrm{N}$ Lat, $156^{\circ} 42^{\prime} \mathrm{W}$ Long). Coll. 1961 by W. A. Davis.

\section{I-527. Smelt Creek Phase, BR9-1}

$850 \pm 120$

Charred wood from fireplace in Site BR9-1, N bank of Brooks River, Alaska (58 $35^{\prime} \mathrm{N}$ Lat, $155^{\circ} 44^{\prime}$ W Long). Coll. 1961. Comment: at Site BR9. 1 Smelt Creek Phase pottery post-dated the deposit of Volcanic Ash 4, but its relationship to Volcanic Ash 3 was obscure because site had been intruded upon in later aboriginal times and Volcanic Ash 3 dug through. Seems likely that this age should pertain to that intrusion, and not to Smelt Creek Phase occupation.

\section{Brooks River Hilltop Phase}

Materials of this phase consist of small basalt adzes with rubbed bits, as well as small flaked bifacies of both chalcedony and igneous rocks, reminiscent in form of those of the Arctic Small Tool tradition (Irving, 1962), and have been recovered from three adjacent sites on $S$ loank of Brooks River, in strata between Volcanic Ash 4 and Volcanic Ash 5.

\section{I-517. Brooks River Hilltop Phase, BR5-1 $3125 \pm 200$}

Charred wood from an isolated hearth, Site BR5-1, on S bank of Brooks 
River, Alaska $\left(58^{\circ} 35^{\prime} \mathrm{N}\right.$ Lat, $155^{\circ} 44^{\prime} \mathrm{W}$ Long). Hearth sealed off from later deposits at site by an unbroken layer of Volcanic Ash 4. Coll. 1961.

\section{Brooks River Gravels Phase}

Materials of this phase include small scrapers and small bifacially flaked end or sideblades of chalcedony, all reminiscent of implements of the Arctic Small Tool tradition from elsewhere in Alaska (Irving, 1962). Of these, the Denbigh Flint Complex, of Norton Bay, has been found to underlie materials dated at $4040 \pm 280$ (Penn IV). Gravels Phase implements from Site BR5-1, including sample reported below, appeared between deposits of Volcanic Ash 4 and Volcanic Ash 5. Age of another component of Gravels Phase, underlying Volcanic Ash 5 at nearby BR3-1 site, has been measured at $3972 \pm 440$ (Yale VII). A sample of peat adjacent to a deposit of Volcanic Ash 5 from a bog along Brooks River is dated at $3860 \pm 90$ (Yale VII). Age for Gravels Phase materials at Site BR5-1 is consequently somewhat less than expected, and reported age seems closer than desirable to that for the succeeding Brooks River Hilltop Phase. This is further discussed elsewhere (Dumond, 1963).

\section{I-518. Brooks River Gravels Phase, BR5-1 $\quad 3250 \pm 200$}

Scattered charred wood believed associated with Gravels Phase deposits, Site BR5-1, Brooks River, Alaska (58 $35^{\prime} \mathrm{N}$ Lat, $155^{\circ} 44^{\prime} \mathrm{W}$ Long). Coll. 1961.

\section{Miscellaneous Determinations, Naknek Drainage and Vicinity}

\section{I-521. Brooks River unassigned assemblage}

$1225+130$

A.D. 725

Charred wood from remains of campfire, Site BR5-1, S bank of Brooks River, Alaska ( $58^{\circ} 35^{\prime} \mathrm{N}$ Lat, $155^{\circ} 44^{\prime} \mathrm{W}$ Long), apparently between Volcanic Ash 3 and Volcanic Ash 4, and believed at time of excavation to be associated with a few implements of flaked stone, and with fragments of pottery bearing linear-stamped exterior decoration, apparently similar both in decoration and paste to ceramics from farther N assigned to Norton Culture. Coll. 1961. Comment: age much less than expected. In view of closeness of age to that of samples assigned to Brooks River Falls Phase, it is possible that charcoal from which this determination was made was also of Falls Phase deposition, and that inferred association with linear-stamped potsherds was erroneous. No similar pottery has been recovered elsewhere in Naknek drainage.

\section{I-505. Kukak Bay, Katmai National Monument $775 \pm 95$}

A.D. 1175

Charred wood, Kukak Bay site, Shelikof Strait coast of Katmai National Monument, Alaska ( $58^{\circ} 19^{\prime} \mathrm{N}$ Lat, $154^{\circ} 10^{\prime} \mathrm{W}$ Long $)$, believed to date earliest level in which pottery was recovered. Coll. 1953 by W. A. Davis (Davis, 1960). Comment: sample associated with materials markedly similar to those of Brooks River Camp Phase. Provides a date for occurrence of pottery in Pacific Eskimo area, and as expected is in agreement with I-525. 


\section{B. Central United States}

\section{I-678. Heins Creek site, Wisconsin}

$$
\begin{array}{r}
1230 \pm 150 \\
\text { A.D. } 720
\end{array}
$$

Burned food adhering to interior of sherds from Heins Creek site $\left(45^{\circ} 1^{\prime}\right.$ N Lat, $87^{\circ} 9^{\prime}$ W Long), on coast of Lake Michigan, 41/4 mi S of Baileys Harbor, Door County, Wisconsin. Obtained by scraping interior surfaces of sherds found in buried humus zone ca. 1 to $2 \mathrm{ft}$ thick ca. $41 / 2 \mathrm{ft}$ beneath aeolian sand and $10 \mathrm{ft}$ above level of Lake Michigan. Coll. 1961 and subm. 1962 by R. J. Mason and C. I. Mason, Lawrence College, Appleton, Wisconsin. Comment (R.J.M.) : sample from pottery types Heins Creek Cordmarked, Heins Creek Corded Stamped, and Heins Creek Cordwrapped-stick Impressed. Date is considered reliable for early late Woodland Heins Creek Complex and is compatible with $\mathrm{C}^{14}$ dates on typologically comparable assemblages in Illinois, Iowa, and New York.

\section{I-744. Sherman Park mounds, South Dakota $1575 \pm 180$}

Human bone from secondary burial at base of Mound 4, Sherman Park Mounds, Site 39 Mn8 (43 ${ }^{\circ}$ N Lat, 97 $\mathrm{W}$ Long), Sioux Falls, South Dakota. Coll. and subm. 1962 by W. R. Hurt. Comment (W.R.H.) : date agrees with archaeological evidence at site and with other dated Middle Woodland burial mounds in E South Dakota (Gant and Hurt, 1963).

\section{I-167. Hell Gap site, Kimble Locations, Wyoming $\quad 10,850 \pm 550$}

Charcoal from Hell Gap Site Kimble location $12 \mathrm{mi} \mathrm{N}$ of Guernsey County, Wyoming $\left(42^{\circ} 24^{\prime} 30^{\prime \prime} \mathrm{N}\right.$ Lat, $104^{\circ} 38^{\prime} 15^{\prime \prime} \mathrm{W}$ Long). Fragments handpicked during archaeological excavations of Hell Gap occupation level. Coll. and subm. 1960 by G. Agogino and V. Haynes. Comment (G.A.) : sample washed and screened in lab. Material smaller than 30 mesh discarded. Remaining rootlets removed by hand. Sample dates time of Hell Gap occupation of a Paleosol believed contemporaneous with Two Creeks Interstadial. Date supports geological interpretation and indicates the contemporaneity of Hell Gap and Folsom peoples in the region.

\section{I-221. Sister's Hill Site, Miami}

Charcoal from Sister's Hill Site $\left(44^{\circ} 16^{\prime} \mathrm{N}\right.$ Lat, $106^{\circ} 46^{\prime} \mathrm{W}$ Long $), 6 \mathrm{mi}$ SW of Buffalo, Johnson County, from vertical stratigraphic interval not exceeding 3 in. Composite of 3 layers representing intermittent occupation over an unknown period of time. Coll. 1960 by E. Galloway, G. Agogino, V. Haynes; subm. 1961 by V. Haynes and G. Agogino. Comment (G.A.) : sample washed and screened in lab. Material smaller than 30 mesh discarded. Remaining rootlets removed by hand. Sample dates average time during which site was occupied by Agate and Hell Gap peoples. Cultural levels on weathering profile believed to correlate with Two Creeks interstadial. Date suggests a compound Paleosol separating the Ucross and Kaycee formations. 


\section{I-245. Hell Gap Site (Frederick Location), Wyoming}

$8600 \pm 600$

6650 в.с.

Charcoal from Scotts Bluff occupation level of Hell Gap Site, Frederick Location $\left(42^{\circ} 24^{\prime} 30^{\prime \prime} \mathrm{N}\right.$ Lat, $104^{\circ} 38^{\prime} 15^{\prime \prime} \mathrm{W}$ Long) $12 \mathrm{mi} \mathrm{N}$ of Guernsey, Goshen County, Wyoming. Coll. 1960 by V. Haynes and G. Agogino; subm. 1961 by V. Haynes and G. Agogino. Comment (G.A.) : sample washed and screened in lab. Material smaller than 30 mesh discarded. Remaining rootlets removed by hand. Sample dates time at which Scotts Bluff and other peoples occupied the site during a period of loess accumulation. A brief halt in loess deposition, either contemporary with or just after occupation, is indicated. Date supports a geologic age estimate of terminal Valders time.

Date lists:

\section{REFERENCES}

$\begin{array}{ll}\text { Michigan V } & \text { Crane and Griffin, 1960 } \\ \text { Penn IV } & \text { Ralph and Ackerman, 1961 } \\ \text { USGS VI } & \text { Rubin and Berthold, 1961 } \\ \text { Yale VII } & \text { Stuiver and Deevey, 1962 }\end{array}$

Agogino, G. A., and Frankforter, W. D., 1960, The Brewster Site: An Agate Basin Folsom multiple component site in Eastern Wyoming: The Master Key, v. 34, no. 3, p. 102 107.

Coulter, H. W., Hussey, K. M., and O'Sullivan, J. B., 1960, Radiocarbon dates relating to the Gubik formation, northern Alaska: U. S. Geol. Survey Prof. Paper 400-B, p. B350351 .

Crane, H. R., and Griffin, J. B., 1960, University of Michigan radiocarbon dates V: Am. Jour. Sci. Radioc. Supp., v. 2, p. 31-48.

Davis, W. A., 1960, Archeological Investigations of Inland and Coastal Sites of the Katmai National Monument, Alaska: Archives of Archaeol., no. 4.

Douglas, L. A., and Tedrow, J. C. F., 1960, Tundra soils of arctic Alaska: Internat. Congress Soil Science, 7 th, Transactions, v. 4, p. 291-304.

Dumond, D. E., 1962, Prehistory in the Naknek drainage: in Research on Northwest Prehistory, by L. S. Cressman and D. E. Dumond: Eugene, Oregon, Univ. of Oregon Dept. of Anthropol., p. 7-54.

- 1963, Two early phases from the Naknek drainage: Arctic Anthropol., v. 1, no. 2 , p. 93-104.

Fairbridge, R. W., 1962, New radiocarbon dates of Nile sediments: Nature, v. 196, p. 108110 .

Gant, R., and Hurt, W., 1963, The 1962 excavations of the Sherman Park mound site, 39 Mn 8: A newly radiocarbon dated site in South Dakota: Mus. News, W. H. Over Museum, State Univ. of South Dakota, Vermillion, v. 24, no. 1.

Haynes, V., and Agogino, G., 1960, Geological significance of a new radiocarbon date from the Lindenmeier site: Denver Mus. of Nat. History, Proc. no. 9, 23 p.

Henoch, W. E. S., 1964, The late-glacial and postglacial isostatic emergence of Melville Island: Geographical Bull. [Ottawa] no. 22.

Ives, J. D., and Andrews, J. T., 1963, Studies in the physical geography of north-central Baffin Island, N.W.T.: Geographical Bull. [Ottawa] no. 19.

Perlmutter, N. M., 1959, Geology and ground-water resources of Rockland County, N. Y. with special emphasis on the Newark Group (Triassic) : New York Water Power and Control Comm. Bull. GW-42, p. 17.

Péwé, T. L., and Church, R. E., 1962, Age of the spit at Barrow, Alaska: Geol. Soc. Am. Bull. 73, p. 1287-1291.

Ralph, E. K., and Ackerman, R. E., 1961, Univ. of Pennsylvania radiocarbon dates IV: Radiocarbon, v. 3 , p. 4-14.

Rubin, M., and Berthold, S. M., 1961, U. S. Geological Survey radiocarbon dates VI: Radiocarbon, v. 3, p. 86-98.

Sim, V. M., 1963, The physical geography of the Foxe Basin North map sheet: Geographical Bull. [Ottawa] no. 20.

Stuiver, M., and Deevey, E. S., 1962, Yale natural radiocarbon measurements VII: Radiocarbon, v. 4 , p. $250-262$. 